\title{
Elimination of hepatitis from Pakistan by 2030: is it possible?
}

\author{
Yasir Waheed ${ }^{1}$, Masood Siddiq² \\ 'Foundation University Medical College, Foundation University Islamabad, Islamabad 44000, Pakistan. \\ 2Jinnah Memorial Hospital, 2-Civil Lines, Rawalpindi 46000, Pakistan.
}

Correspondence to: Dr. Yasir Waheed, Foundation University Medical College, Foundation University Islamabad, Islamabad 44000, Pakistan. E-mail: yasir_waheed_199@hotmail.com; Prof. Masood Siddiq, Jinnah Memorial Hospital, 2-Civil Lines, Rawalpindi 46000, Pakistan. E-mail: dr.masood.siddiq@gmail.com

How to cite this article: Waheed Y, Siddiq M. Elimination of hepatitis from Pakistan by 2030: is it possible? Hepatoma Res 2018;4:45. http://dx.doi.org/10.20517/2394-5079.2018.58

\author{
Received: 14 May 2018 First Decision: 20 Jun 2018 Revised: 17 Jul 2018 Accepted: 30 Jul 2018 Published: 14 Aug 2018 \\ Science Editor: Guang-Wen Cao Copy Editor: Jun-Yao Li Production Editor: Cai-Hong Wang
}

\begin{abstract}
Globally 71 million people are living with hepatitis C virus (HCV) out which 7.1 million (10\%) are present in Pakistan. Genotype 3 is the most common HCV type in the country. World Health Organization is working with health authorities in different countries for effective control of $\mathrm{HCV}$, to reduce its incidence by $90 \%$ and to reduce hepatitis related mortality by $65 \%$ by the year 2030 . There are several challenges that hinder elimination of HCV from Pakistan including the lack of patient awareness about the causes and transmission of disease, lack of affordability for investigations and drug treatment and lack of experienced healthcare professionals. Other major contributors to achieve HCV elimination are lack of effective drugs and delayed regulatory approvals combined with compromised monitoring by health authorities and lack of robust epidemiological data. Efforts are needed to educate the public about the modes of transmission and prevention of HCV infection, and massively upscale screening along with treatment. There is a dire need to prevent more than 200,000 new infections that occur each year in Pakistan. Given the scale of the problem, it is very unlikely that the government alone can handle it.
\end{abstract}

Keywords: Hepatitis C virus, global health sector strategy, hepatitis elimination, national hepatitis strategic framework, punjab hepatitis ordinance, hepatitis diagnosis, screening

\section{OPINION}

Viral hepatitis caused 1.4 million deaths in 2015, which is comparable with the annual deaths from tuberculosis and higher than the annual deaths from $\mathrm{HIV}^{[1]}$. The hepatitis epidemic remained neglected for 
many years until 2015, the global burden of disease figure came out ${ }^{[2]}$ and hepatitis is considered as the 7 th leading cause of deaths worldwide. After that hepatitis is included in the Sustainable Development Goals by United Nations ${ }^{[2]}$. World Health Organization (WHO) has developed a Global Health Sector Strategy (GHSS) to eliminate viral hepatitis by 2030. The major goals of GHSS on viral hepatitis are to reduce hepatitis incidence by $90 \%$ and to reduce hepatitis mortality by $65 \%$ by $2030^{[3]}$. Globally, 71 million people were living with hepatitis C virus (HCV) in 2015 and 75\% of them were living in lower and middle-income countries. According to the Polaris Observatory, 7.1 million hepatitis $\mathrm{C}$ cases are present in Pakistan, which covers about $10 \%$ of the global HCV burden ${ }^{[4,5]}$.

WHO is working with health authorities in different countries to develop effective hepatitis control programs, and to achieve hepatitis elimination by 2030. As of November 2017, 84 countries have developed national plans and strategies to control hepatitis ${ }^{[5]}$. Nine countries (Iceland, Qatar, Australia, Georgia, Japan, Netherlands, Egypt, France, and Germany) are on track to achieve HCV elimination targets by 2030, 22 countries are working towards elimination and Pakistan is among the countries in which HCV elimination is un-achievable with its present policy ${ }^{[6]}$.

The government of Pakistan has launched the National Hepatitis Strategic Framework (2017-2021) in October, 2017. Effective implementation of NHSF depends on the concerted Federal and Provincial actions from all stake holder in the health and other sectors to respond to viral hepatitis ${ }^{[7]}$. The major routes of hepatitis transmission in Pakistan are unscreened blood transfusions, shaving from barbers, reuse of needles and syringes and reuse of the same dental and surgical instruments for different patients ${ }^{[8]}$. Pakistan is the country with the highest number of therapeutic injections per person per year. The most dominant genotype of hepatitis $\mathrm{C}$ in Pakistan is $3^{[8]}$. The conventional and Pegylated Interferon based therapy also showed good results in Pakistani patients in the last decade as compared with genotype 1 patients ${ }^{[9-11]}$. The Sofosbuvir based therapy showed excellent response in Pakistani Hepatitis C patients ${ }^{[12]}$. There is a dire need to speed up the registration and availability of new direct acting antivirals for Hepatitis in Pakistani market.

There is a strong need for early diagnosis and treatment of HCV in Pakistan. According to WHO's progress report on access to hepatitis C treatment, 161,000 HCV patients got treatment in Pakistan in the year 2016 (mostly through the private sector) ${ }^{[5]}$. A recent modelling study suggests that Pakistan needs to scale up its HCV treatment number (up to 880,000 treatments per year), to achieve the GHSS targets on viral hepatitis. The treatment number can be minimized (to 525,000 per year) by targeting the treatment to people who inject drugs and people living with cirrhosis and through scaling up prevention interventions ${ }^{[13]}$. Recently, Punjab provincial government has promulgated the Punjab Hepatitis Ordinance 2017. Hopefully this ordinance will play an important role in controlling hepatitis in the province.

Pakistan also needs to improve its HCV surveillance system. According to a national survey conducted in $2007,4.8 \%$ of the Pakistani population was living with $\mathrm{HCV}^{[14]}$, which according to current population estimates (207 million) constitutes about 9.9 million HCV cases, while the Center for Disease Analysis estimates suggests the presence of 7.1 million HCV cases in the country ${ }^{[4]}$.

There is a strong need to speed up the HCV diagnosis and find the missing millions living with HCV. Globally, only about one in five people affected with HCV in 2016 had been diagnosed ${ }^{[5]}$. Non-governmental organizations (NGOs) are playing a significant role in the fight against hepatitis across the globe. There is no funding specifically allocated for the NGOs' work on hepatitis elimination in Pakistan. The prevalence of Hepatitis is very high in high-risk population groups including people who inject drugs, thalassemia patients and refugees ${ }^{[15,16]}$. There is a dire need to start HCV micro-elimination projects in high-risk population groups including people who inject drugs, transgender population, and homeless people. 
Egypt, a lower middle-income country, showed excellent commitments in the fight against hepatitis. By September 2017, a cumulative total of 1.5 million people had received HCV treatment in the country ${ }^{[5]}$. The Ministry of Health and Population of Egypt is planning to screen 15 million Egyptians for the presence of HCV in 2018. World Bank offered to lend the ministry \$200 million to assist its plan to screen 15 million Egyptians for the presence of $\mathrm{HCV}^{[17]}$.

Pakistan also needs to show strong political and financial commitments in the fight against hepatitis. Modelling techniques suggest that HCV can become a rare disease in the next 20-25 years, with a significant financial commitment ${ }^{[18]}$. Extensive HCV treatment and preventive measures are required in Pakistan to achieve the HCV elimination targets in WHO's GHSS on viral hepatitis, without which Pakistan's HCV burden will increase markedly.

The elimination of Hepatitis from Pakistan by 2030 seems impossible with the current initiatives. It will be a significant impact if the country succeeded in controlling the hepatitis from the country and reduced the annual hepatitis deaths from 200,000 to less than 25,000. The control of hepatitis epidemics requires political will, financial investment and support from pharmaceutical, medical and civil societies around the globe $\mathrm{e}^{[19]}$.

\section{DECLARATIONS}

\section{Authors' contributions}

Design: Waheed Y, Siddiq M

Literature research: Waheed Y, Siddiq M

Data analysis: Waheed Y, Siddiq M

Manuscript writing: Waheed Y, Siddiq M

Manuscript editing: Waheed Y, Siddiq M

Manuscript revision: Waheed Y, Siddiq M

\section{Availability of data and materials}

Not applicable.

\section{Financial support and sponsorship}

None.

\section{Conflicts of interest}

Both authors declared that there are no conflicts of interest.

\section{Ethical approval and consent to participate}

Not applicable.

\section{Consent for publication}

Not applicable.

\section{Copyright}

(c) The Author(s) 2018.

\section{REFERENCES}

1. GBD 2013 mortality and causes of death collaborators. Global, regional and national age-sex specific all cause and cause specific mortality for 240 causes of death, 1990-2013: a systematic analysis for the global burden of diseases study 2013. Lancet 2015;385:117-71.

2. Waheed Y. Transition from millennium development goals to sustainable development goals and hepatitis. Pathog Glob Health 
2015;109:353.

3. World Health Organization. Global Health Sector Strategies on Viral Hepatitis 2016-2021. Published 22 April 2016. Available from: http://apps.who.int/gb/ebwha/pdf_files/WHA69/A69_32-en.pdf?ua=1. [Last accessed on 9 Aug 2018]

4. Polaris Observatory HCV collaborators. Global prevalence and genotype distribution of hepatitis C infection in 2015: a modelling study. Lancet Gastroenterol Hepatol 2017;2:161-76.

5. World Health Organization. Progress report on access to hepatitis $C$ treatment, focus on overcoming barriers in low and middle income countries. Published March 2018. Available from: http://apps.who.int/iris/bitstream/10665/260445/1/WHO-CDS-HIV-18.4-eng. pdf?ua=1. [Last accessed on 9 Aug 2018]

6. Polaris Observatory. Center for Disease Analysis. Available from: http://cdafound.org/polaris/. [Last accessed on 9 Aug 2018]

7. National Hepatitis Strategic Framework for Pakistan (2017-2021). Available from: http://phrc.org.pk/Extra/NHSF.pdf. [Last accessed on 9 Aug 2018]

8. Waheed Y, Shafi T, Safi, SZ, Qadri I. Hepatitis C virus in Pakistan: a systematic review of prevalence, genotypes and risk factors. World J Gastroenterology 2009;15:5647-53.

9. Aziz H, Ather MA, Murtaza S, Irafan J, Waheed Y, Bilal I. Predictors of response to antiviral therapy in patients with chronic hepatitis C from Pakistani population. Chin Med J 2011;124:1333-7.

10. Aziz H, Gil ML, Waheed Y, Adeeb U, Raza A, Bilal I, Athar MA. Evaluation of prognostic factors for peg interferon alfa-2b plus ribavirin treatment on HCV infected patients in Pakistan. Infect Genet Evol 2011;11:640-5.

11. Aziz H, Raza A, Waheed Y, Gill U, Gil ML. Analysis of variables and interactions among variables associated with a sustained virological response to pegylated interferon alpha 2 a plus ribavirin in hepatitis $\mathrm{C}$ virus genotype 3 infected patients. Int $\mathrm{J}$ Infect Dis 2012;16:e597-602.

12. Jamil Z, Waheed Y, Malik M, Durrani AA. Effect of sofosuvir plus ribavirin therapy on hepatitis C patients in Pakistan: a retrospective study. Peer J 2018;6:e4853.

13. Lim AG, Qureshi H, Mahmood H, Hamid S, Davies CF, Trickery A, Glass N, Saeed Q, Fraser H, Walker JG, Mukandavire C, Hickman M, Martin NK, May MT, Averhoff F, Vickerman P. Curbing the hepatitis C virus epidemic in Pakistan: the impact of scaling up treatment and prevention for achieving elimination. Int J Epidemiology 2018; doi: 10.1093/ije/dyx270.

14. Qureshi H, Bile KM, Jooma R, Alam SE, Afridi HUR. Prevalence of hepatitis B and C viral infections in Pakistan: findings of a national survey appealing for efeective prevention and control measures. East Mediterr Health J 2010;16:S15-23.

15. Saeed U, Waheed Y, Ashraf M, Waheed U, Anjum S, Afzal MS. Estimation of hepatitis B virus, hepatitis C virus, and different clinical parameters in the thalaseemic population of capital twin cities of Pakistan. Virology (Auckl) 2015;6:11-6.

16. Waheed Y, Najmi MH, Aziz H, Waheed H, Imran M, Safi SZ. Prevalence of hepatitis C in people who inject drugs in the cities of Rawalpindi and Islamabad, Pakistan. Biomed Rep 2017;7:263-6.

17. Omran H. World Bank to lend Health Ministry $\$ 200 \mathrm{~m}$ for hepatitis C screening: minister. Available from: https://dailynewsegypt. com/2018/03/28/world-bank-lend-health-ministry-200m-hepatitis-c-screening-minister/. [Last accessed on 9 Aug 2018]

18. Papatheodoridis GV, Hatzakis A, Cholongitas E, Baptista-Leite R, Baskozos I, Chhatwal J, Colombo M, Cortez-Pinto H, Craxi A, Goldberg D, Gore C, Kautz A, Lazarus JV, Mendão L, Peck-Radosavljevic M, Razavi H, Schatz E, Tözün N, van Damme P, Wedemeyer H, Yazdanpanah Y, Zuure F, Manns MP. Hepatitis C: the beginning of the end-key elements for successful European and national strategies to eliminate HCV in Europe. J Viral Hepatitis 2018;Suppl 1:6-17.

19. Waheed Y. Hepatitis C eradication: a long way to go. World J Gastroenterol 2015;21:12510-2. 